\title{
The Obama Administration's Proposals to Address Concentrated Urban Poverty
}

\section{Citation}

Wilson, William Julius. 2010. The Obama Administration's Proposals to Address Concentrated Urban Poverty. City and Community 9(1): 41-49.

\section{Published Version}

http://onlinelibrary.wiley.com/doi/10.1111/j.1540-6040.2009.01315.x/abstract

\section{Permanent link}

http://nrs.harvard.edu/urn-3:HUL.InstRepos:4778627

\section{Terms of Use}

This article was downloaded from Harvard University's DASH repository, and is made available under the terms and conditions applicable to Other Posted Material, as set forth at http:// nrs.harvard.edu/urn-3:HUL.InstRepos:dash.current.terms-of-use\#LAA

\section{Share Your Story}

The Harvard community has made this article openly available.

Please share how this access benefits you. Submit a story.

Accessibility 
The Obama's Administration's Proposals to Address Concentrated Urban Poverty William Julius Wilson

Harvard University

Prior to the arrival of the Obama Administration, a fundamental shift in the federal government's support for basic urban programs aggravated problems in inner-city neighborhoods. Beginning in 1980, when Ronald Reagan became President, sharp spending cuts on direct aid to cities dramatically reduced budgets for general revenue sharing-unrestricted funds (that can be used for any purpose)—urban mass transit, economic development assistance, urban development action grants, social service block grants, local public works, compensatory education, public service jobs, and job training. Many of these programs are designed to help disadvantaged individuals gain some traction in attaining financial security (Caraley, 1992). It is noteworthy that the federal contribution was 17.5 percent of the total city budgets in 1977 , but only 5.4 percent by 2000 (Wallin 2005).

These cuts were particularly acute for older cities in the East and Midwest that largely depended on federal and state aid to fund social services for their poor population and to maintain aging infrastructure. For example, in 1980, federal and state aid funded 50 to 69 percent of the budgets in six of these cities, and 40 to 50 percent of budgets in eleven cities. By 1989 only three cities --Buffalo, Baltimore, and Newark - continued to receive over fifty percent of their budgets in state aid, and only two cities - Milwaukee and Boston - received between 40 to 50 percent of 
their budgets in state aid. To further illustrate, New York City's state aid dropped from $52 \%$ of its budget in 1980 to $32 \%$ in 1989 , which resulted in a loss of $\$ 4$ billion (Caraley 1992).

Barack Obama entered the presidency with a pledged to take seriously the role of the federal government in supporting urban America. He created a White House Office of Urban Affairs, with the Director reporting directly to the President. And programs designed to strengthened metropolitan areas have been spread across the federal government-including the Department of Education, the Department of Housing and Urban Development, and the Department of Labor. Among these programs are special initiatives to address the problems of concentrated urban poverty, which have become especially acute since the early 1970s. And, as we shall soon see, the Obama administration seemed to be aware of the need to address this growing problem, especially in the poor African American neighborhoods.

In the earlier years communities undergoing racial change from white to black tended to experience an increase in population density, as a result of the black migration from the South. Because of the housing demand, particularly in the late stages of the succession from white to black, homes and apartments in these neighborhoods were often subdivided into smaller units (Quillian 1999). However, 1970 marked the end of the great migration wave of blacks from the South to northern urban areas, and two developments affected the course of population movement to the inner cities after that time. Improvements in transportation made it easier for workers to live outside the central city, and industries gradually shifted 
to the suburbs due to the increased residential suburbanization of the labor force and the lower cost of production. Because of the suburbanization of employment and improvements in transportation, inner-city manufacturing jobs were no longer a strong factor pulling migrants to central cities (Quillian 1999).

So with the decline of industrial employment in the inner city, the influx of southern black migration to northern cities ceased and many poor black neighborhoods, especially those in the Midwest and Northeast, changed from densely packed areas of recently arrived migrants to communities gradually abandoned by the working and middle classes (Wilson 1987, Wilson 1996 and Quillian 1999).

The problems in these neighborhoods are sometimes severe, including high concentrations of poverty, partly due to the outmigration of higher income families, joblessness, crime, and poor performing schools. Research suggests that the adverse effects of living in such neighborhoods are not solely structural. Among the effects of living in poor segregated neighborhoods over extended periods is repeated exposure to cultural traits that emanate from or are the products of racial exclusion, traits such as verbal skills, that may impede successful maneuvering in the larger society (Sharkey 2008, and Sampson, Sharkey, and Raudenbush 2008).

To address the problems in poor segregated neighborhoods I have argued for a holistic public policy perspective whereby the complex web of structural and cultural factors that create and reinforce racial inequality are recognized and appreciated (Wilson 2009). As suggested above, with their initiatives to combat the problems of concentrated poverty, there are clear indications that the Obama 
Administration is adopting such holistic initiatives. One such initiative is the Department of Housing and Urban Development's Choice Neighborhood program, which in effect is designed to replace HOPE VI-launched in the early 1990s to help overcome the adverse effects of public housing projects in blighted neighborhoods (on HOPE VI, see Michael B. Katz's article in this issue). With a proposed budget of $\$ 250$ million for fiscal year 2010, the Choice Neighborhood initiative represents a net increase of $\$ 130$ million over the baseline for HOPE VI. As a pilot project, the program will fund competitive grants averaging $\$ 25$ to $\$ 35$ million to local governments, public housing authorities, nonprofits, and for-profit developers in up to 10 neighborhoods (see Margery Austin Turner's article in this issue). The Choice Neighborhoods program will also require matching funds from local, state, or private sources.

The Choice Neighborhood initiative goes beyond the rehabilitation of physically deteriorated public housing neighborhoods, the focus of HOPE VI, and includes comprehensive neighborhood investments ranging from early childhood education to employment, safety, and transportation components. Indeed, this holistic program even contemplates integrating some of its service with the Obama Administration's proposed Promise Neighborhood initiative in twenty cities across the country. Whereas it is difficult to get a clear sense of the Choice Neighborhood initiative because of its infancy and because it is not modeled after a program that has been rigorously evaluated, this is not the case with the Promise Neighborhoods. Indeed, with considerable fanfare the Obama Administration announced that his 
Promise Neighborhoods initiative would be patterned after the successful Harlem Children's Zone (HCZ).

As a holistic approach to the problems of concentrated poverty, The HCZ was developed by the visionary Geoffrey Canada whose mission was to flood a number of blocks in Harlem with educational, social, and medical services to create a comprehensive safety net for the children in that area (Tough 2008). More specifically, the HCZ is a ninety-seven block laboratory in central Harlem that combines two reform-oriented charter schools with a web of community services designed for children from birth to college graduation in order to provide a supportive and positive social environment outside the schools (Dobbie and Fryer 2009). Canada was able to get corporate leaders to support him, and he now has an annual budget of roughly $\$ 64$ million.

The HCZ features over 20 programs that represent a combination of structural and cultural interventions to help and empower individuals who live in these 97 blocks. Included in these investments are those ranging from family and health programs, and community programs to childhood programs such as Head Start, after-school programs that include tutoring, dance, and karate, and an all daypre-kindergarten program call Harlem Gems, which has a 4:1 child to adult ratio. The intensive curriculum in the Harlem Gems "is designed to increase socialization skills, build routines, and begin development of the language and pre-literacy skills students need in kindergarten. The Gems program includes a number of nontraditional subjects such as Spanish and French and parents are strongly 
encouraged to volunteer at the school and become more involved in their child's education" (Dobbie and Fryer 2009:6).

While most of the community programs represent structural interventions, and some combine structural and cultural interventions such as the Harlem Gems, one notable community program, The Baby College, in clearly cultural in orientation. The Baby College is a nine-week workshop for expectant parents and those with children up to the age of three. The curriculum is based on the writings and counsel of the pediatrician T. Berry Brazleton and feature subjects that range from handling parental stress, alternatives to physical discipline, the importance of prenatal care, and parent-child bonding, including attempts to encourage parents to read to their children (Brazleton 1992).

The school investment features the Promise Academy charter schools, a major structural intervention. The first Academy (Promise Academy 1) was opened in 2004 with elementary and middle schools. And the second Academy (Promise Academy 2) was opened in the fall of 2005 with an elementary school. Both Promise Academy 1 and Promise Academy 2 will eventually reach a full k to 12 set of grades, taking on a new grade each year.

As Dobbie and Fryer point out, "a slew of anecdotal evidence suggests that the [HCZ's] approach is working. For six straight years, 100 percent of prekindergarteners were school ready in the Harlem Gems program. Eighty-one percent of parents who have attended The Baby College report reading to their child more often than they had done previously" (Dobbie and Fryer, 2009:7). However, this is not the most rigorous evidence for the success of the program because the 
children enrolled in Harlem Gems and the parents enrolled in the Baby College were not randomly selected. In other words, there could be some self-selection bias here. The most rigorous evidence suggesting the success of the program comes from a random assignment evaluation by the Harvard economist Roland Fryer. Fryer took advantage of the fact the HCZ's charter schools are required to select students by lottery. This allowed him to create a treatment group and a control group. The treatment group is composed of students who were selected by the lottery and the control group consists of students who are lottery losers (Dobbie and Fryer 2009).

The preliminary results of this evaluation are spectacular. Here we have children from some of the most impoverished backgrounds, mostly from poor single-parent families, whose scores on the cognitive tests far exceed those of children in the public schools of New York, including those who were losers in the HCZ's lottery. Students who entered the Promise Academies in the sixth grade experienced a full standard deviation gain in math and between one-third and onehalf standard deviations in English Language Arts (ELA) by the eight grade. "Taken at face value, these effects are enough to reverse the black-white achievement gap in mathematics (HCZ students outperform the typical white student in New York city and the difference is statistically significant) and reduce it in ELA." (Dobbie and Fryer 2009:3).

However, the results are even more spectacular for the students in the Promise Academy elementary schools, student who benefited from entering the Promise Academies when they were in kindergarten. The elementary school students closed the black-white achievement gap in both mathematics and English Language Arts, 
gaining approximately one and three-quarters of a standard deviation in each subject (Dobbie and Fryer 2009).

The closing of the English Language Arts gap in elementary school and significantly reducing it in middle school are especially noteworthy achievements. Careful research reveals that living in poor segregated neighborhoods for extended periods of time has an adverse affect on verbal ability, as measured by the cognitive tests. And these effects linger on even after children leave these neighborhoods (Sampson, Sharkey, and Raudenbush 2008). So it is much more difficult to overcome the affects of living in chronic economically poor segregated neighborhoods on verbal skills of older children. Nonetheless, even the ELA scores of students in the HCZ were significantly higher than those in the control group, and, to repeat, the ELA scores for those in the Academy's elementary schools were especially dramatic. And now Geoffrey Canada and his staff have decided to select children for this program from a lottery at the time they're born. As this program continues, the ELA scores will undoubtedly improve significantly for those beyond elementary school because they will have the benefit of the earliest exposure to the HCZ. This is very important because beginning at earliest point in a child's life would be an effective way to offset the cumulative effects of living in poor segregated neighborhoods.

Finally, Promise Academy students are in school nearly twice as long as the typical public-school student, including an extended school day, with coordinated after-school tutoring and additional classes on Saturdays for students who need remediation in English Language Arts and mathematics skills, and a relatively short 
summer vacation. Nonetheless, the lottery winners are absent less in every grade than the control group of lottery losers (Dobbie and Fryer 2009).

However, despite the spectacular success of the HCZ, the program has its critics. One of the most frequent criticisms relates to the issue of self-selection bias. It is argued that one of the reasons why public charter schools like those in the HCZ out-perform traditional public schools is because the parents who enroll their children in charter schools tend to be more concerned about their children's education in traditional public schools and therefore more motivated to seek other educational opportunities (Kahlenberg 2009). While it is true that the parents who enter the lottery for the Promised Academies may represent a group different from those who did not choose to enter the lottery, this criticism fails to address the substantial differences in the test scores of the lottery winner and lottery losers. When a random lottery among applicants is held for a public charter school because the demand exceeds the supply and the lottery winners and losers have applied to the same school, the difference in selection between the two groups is eliminated.

A far more challenging criticism has to do with factors driving the success of the HCZ Promised Academies, not the degree to which the program is successful. The HCZ is premised on the assumption that to fully address the learning gap of poor black students it is necessary to not only improve the schools in which the students attend, but the neighborhoods in which they live as well. Indeed, this is one of the basic assumptions of Obama's Promised Neighborhood program. However, As Robert Embry Jr. reminded me, there are other public charter schools in the United States heavily populated with poor students of color, many of whom 
performed poorly in the traditional public schools, whose student performances also far exceed those in the traditional public schools without the bungle of community supports that characterize the HCZ. ${ }^{1}$

One of the most frequently mentioned in The KIPP (Knowledge is Power Program) academies where the "weight of the evidence suggest that students who enter and stay in KIPP tend to perform better than similar students in more traditional public schools" (Kenig, 2008:3). But, unlike the evidence for the success of Promise Academy students, the empirical studies on the success of the KIPP program have not been based on a randomized designed. ${ }^{2}$

However, recent systematic randomized studies of public charter schools in Boston and New York, schools that are lottery-based, provide the most compelling evidence to suggest that schools can elevate the success of poor students and students of color independent of community or neighborhood investments (Abdulkadiroglu et. al. 2009; Hoxby, Murarka, and Kang 2009). In the Boston public charter schools, like many other urban public charter schools, a substantial majority of the students are African American-75 percent in elementary school, 70 percent in middle school, and 68 percent in high school (Abdulkadiroglu et. al. 2009). Using a randomized lottery restricted to schools that were oversubscribed as well as statistical controls to measure background characteristics, Abdulkadiroglu and his colleagues found large positive effects for Boston public charter Schools, at both the middle school and high school levels (elementary charter students were not included in this study). For each year of attendance in middle school, the researcher estimated that "Charter Schools raise student achievement .09 to .17 standard 
deviations in English Language Arts and .18 to .54 standard deviations in math relative to those attending traditional schools in the Boston Public Schools" (Abdulkadiroglu et. al. 2009:9)

The estimated .5 standard deviation impact on math achievement for the students in Charter middle schools is "the same as moving from the 50th to the 69th percentile in student performance. This is roughly half the size of the black- white achievement gap" (Abdulkadiroglu et. al. 2009). The estimated gains in high school are significant but somewhat smaller. Although these results are notable, one problem with the study is that the lottery-based estimates for the Charter Schools were limited to those subjected to lotteries every year. Some Charter Schools were unable to fill all of their open slots. "To the extent that over-subscription is a sign of quality, the lottery-based estimates may systematically exclude some of the less desirable schools" Abdulkadiroglu et. al. 2009:32). Indeed some critics of charter schools were quick to dismiss the findings on that basis. Kahlenberg for instance argues that since "the only charter schools included in the study were the 26 percent that were popular and oversubscribed ... the findings of superior performance compared with the public schools generally was unsurprising" (Kahlenberg, 2008:17). Such criticism could not be applied to the recently released rigorous study of the New York public charter schools (Hoxby, Murarka, and Kang 2009).

The distinctive feature of the study by Hoxby and her colleagues is that they were not only able to estimate the effects of the New York charter schools on achievement by using the "gold standard" method of lotteries, but they were able to 
include nearly all the students enrolled in the public charter schools in New York because "94 percent of charter school students in New York City are admitted to a school after having participated in a random lottery for school places" (Hoxby, Murarka, and Kang 2009: v). Public charter schools in New York City are generally concentrated in Harlem and the South Bronx, with a few others in Brooklyn and Queens, and they draw from an overwhelmingly black and Hispanic student population. Whereas 61 percent of the students who enrolled in the New York public charter schools were black and 29 percent were Hispanic, only 4 percent were white. By contrast 34 percent of the students in New York City's traditional public schools are black, 15 percent are white, and 38 percent are Hispanic. Also, the charter school applicants are poorer than the average student in the traditional public school (Hoxby, Murarka, and Kang 2009).

Hoxby and her colleagues found that on average, a student who attended a charter school from the kindergarten to the eight grade would close about 86 percent of the "Scarsdale-Harlem" achievement gap in math and 66 percent of the gap in English. ${ }^{3}$ The improvement would be commensurately smaller for a student who attended fewer grades. By contrast the lottery losers who remain in the traditional public schools for all grades from kindergarten to eight "would stay on grade level but would not close the 'Scarsdale-Harlem' achievement gap by much" (Hoxby, Murarka, and Kang 2009:IV-1) ${ }^{4}$

What the successful Boston and New York charter schools, as well as the Promise Academy charter schools in the HCZ, have in common is that they are independent and fairly autonomous and therefore can pay teachers on the basis of 
performance or duties as opposed to traditional pay scales that put the spot light on seniority and credentials; and they all have an extended school day and a long school year.

So, given the results of these successful public charter schools, especially the results from the rigorous evaluation of the New York public charter schools, we return to the question of whether the notable educational outcomes observed in the HCZ Promised Academies could have been achieved independent of the bundle of community investments.

Even the Dobbie and Fryer evaluation of the Harlem Children Zone, which was mainly focused on the factors that contributed to successful educational outcomes in the Promise Academies, raised questions about the role of the community investments. Whereas only the approximately 1300 students who attend the Promise Academy charter schools have access to the school programs, ${ }^{5}$ the community programs in the $\mathrm{HCZ}$ "are available to anyone living near $\mathrm{HCZ}$, and serve over 7,400 children and over 4,100 adults" (Dobbie and Fryer 2009:6).

Addressing the important question about the impact of the bundle of community service on the educational outcomes of the Promise Academy children, Dobbie and Fryer considered several pieces of evidence-a comparison of the lottery winners with the other children inside the Zone's who were either lottery losers or did not apply for the lottery; a comparison of students in the Promise Academies who lived inside the zone and the smaller subsample of students who attended the Academies but lived outside the zone, and anecdotal evidence in the years before the opening of the Promise Academy charter schools that the HCZ 
program was unsuccessful—and concluded that community investment alone cannot explain the school achievement outcomes. However, they were unable "to disentangle whether communities coupled with high-quality schools" drove their results or "whether the high-quality schools alone are enough to do the trick" (Dobbie and Fryer, 2009, p. 4).

Based on this preliminary evidence, should Obama's Promise Neighborhoods focus mainly on school investments, given the cost of a comprehensive community investment program? Robert Embry Jr's comment is appropriate in this regard. He states: "Resources are limited and should be spent in the most cost effective way. If the objective is to increase test scores on standardized tests, and/or increase high school graduation and decrease drop outs, and/or increase college attendance for low-income children from areas of concentrated poverty, then with limited resources we should ask how should these resources be spent to most positively impact these indicators." 6 This is a thoughtful and reasonable question.

However, the focus of the HCZ, and the focus of the Promised Neighborhoods, which will be patterned after it, is not confined to educational outcomes, however important. There are other outcomes ranging from delinquency and gangs to teen pregnancy and mental and physical health that the program hopes to address. Many of these outcomes can only be adequately measured over time. Indeed, Geoffrey Canada has argued that it is too early to measure community impacts because they will begin to show up later as the children approach and enter college. "We'll see the impact five or six years from now," he states, "when there are working adults and no longer going to prison."7 
A comprehensive study is now under way to measure such long-term impacts not only on educational outcomes, but other outcomes that relate to the various community investments. Roland Fryer has pulled together a team of economists and sociologists at Harvard University to develop and analyze comprehensive sets of quantitative and qualitative data, including data that examine both the structural and cultural impacts of the program over time, for an evaluation of all aspects of the HCZ. One of the goals is to provide a detailed theory to explain the overall success of this program, a theory that will be based on a careful analysis of the quantitative and qualitative evidence. Hopefully this theory will provide the guidelines for scaling up and evaluating the Twenty Promised neighborhoods to be developed across the country.

The Obama Administration has proposed spending \$10 million on planning grants in the 2010 fiscal to help in the creating of Promise Neighborhoods in the 20 cities. Request for proposals to help nonprofits create Promise Neighborhoods will go out in early 2010 , and grants will be awarded to the most competitive proposals. Administration officials have already indicated that winning proposals will have to have a solid plan in place to measure performance. Obviously, $\$ 10$ million is only a small fraction of what will be needed to fully implement these programs. Money for the implementation is likely to made available the following year. In his initial discussion of these programs Mr. Obama emphasized that billions of dollars would be needed and would have to come from a consortium of funders-government, philanthropies and businesses. 
In any case, it is very important that this important pilot project be successful if there is any hope of scaling up the program to reach more children and adults. And the evidence collective thus far suggest that perhaps the most important components of the Promise Neighborhoods will be public charter schools that include many of the features found in the HCZ Promised Academies, and in the successful public charter schools of New York and Boston.

Some believe that only a charismatic leader like Geoffrey Canada can successfully implement a program patterned after the HCZ. However, Canada did not have the benefit of an empirically based theory to guide him in the creation of the program. He had a lot of hits and misses until the program finally evolved into the apparently successful intervention it is today (Tough 2008). If Roland Fryer and his research team are able to develop an empirically based theory to explain various outcomes of the HCZ, the most important trait for the future directors of the Promise Neighborhoods will not be charismatic leadership, but the ability to successfully implement the program along the lines suggested by the theory.

\section{Endnotes}

${ }^{1}$ Robert C. Embry Jr., private communication, June 9 and June 10, 2009.

${ }^{2}$ Mathematica has begun a large-scale study of KIPP with a randomized design. However, the results will not be known for at least five years (Henig 2008).

${ }^{3}$ The "Scarsdale Harlem" achievement gap refers to the point spread between poor students of color in Harlem and white students in the affluent suburbs of New York.

${ }^{4}$ Significant differences between the lottery losers and winners were also 
found at the high school level. Hoxby et. al state: "Compared to his lotteried-out counterparts, a student who attends a charter high school has Regents examination scores that are about 3 points higher for each year he spends in the charter school before taking the test. For instance, a student who took the English Comprehensive exam after three years in charter school would score about 9 points higher. A student who attends a charter high school is about 7 percent more likely to earn a Regents diploma by age 20 for each year he spends in that school" (Hoxby, Murarka, and Kang 2009:IV-1).

${ }^{5}$ In additional to various educational programs, "the schools provide free medical, dental and mental-health services (students are screened upon entry and receive regular check-ups), student incentives for achievement (money, trips to France, e.g.), high-quality, nutritious, cafeteria meals, support for parents in the form of food baskets, meals, bus fare, and so forth, and less tangible benefits such as the support of a committed staff. The schools also make a concerted effort to change the culture of achievement, surrounding students with the importance of hard work in achieving success. These types of school policies are consistent with those that argue high- quality schools are enough to close the achievement gap" (Dobbie and Fryer, 2009:7).

${ }^{6}$ Robert Embry Jr., Private Communication, June 9, 2009.

${ }^{7}$ Quoted in Shulman, 2009.

\section{References}


Abdulkadiroglu Atila, Josh Angrist, Susan Dynarski, Jon Fullerton, Thomas

Kane, and Parag Pathak. 2009. Informing the Debate: Comparing Boston's Charter, Pilot and Traditional Schools. Boston: The Boston Foundation.

Brazelton, T. Berry. 1992. Touchpoints: Your Child's Emotional and

Behavioral Development. Reading Massachusetts: Perseus Books.

Caraley, Demetrios. 1992. “Washington Abandons the Cities,” Political

Science Quarterly 107 (Spring): 1-30.

Dobbie, Will and Roland G. Fryer, Jr. 2009. “Are High-Quality Schools Enough to Close the Achievement Gap? Evidence from a Bold Social Experiment in Harlem." NBER Working Paper No. 15473.

Henig. Jeffrey R. 2008. What Do We Know About the Outcomes of KIPP

Schools? East Lansing, Michigan: Great Lakes Center for Education Research \& Practice, March.

Hoxby, Caroline M., Sonali Murarka, and Jenny Kang. 2009. How New York

City's Charter Schools Affect Achievement, August 2009 Report. Cambridge, MA: New York City Charter Schools Evaluation Project, September.

Kahlenberg, Richard D. 2009. Turnaround Schools That Work: Moving Beyond Separate but Equal, New York: The Century Foundation.

Quillian, Lincoln. 1999. “Migration Patterns and the Growth of High-Poverty Neighborhoods, 1970-1990.” American Journal of Sociology 105:1-37.

Sampson, Robert J., Patrick Sharkey, and Stephen W. Raudenbush. 2008.

“Durable Effects of Concentrated Disadvantage on Verbal Ability among African- 
American Children." Proceedings of the National Academy of Sciences of the United States of America 105 (January 22):845-852.

Sharkey, Patrick. 2008. "The Intergenerational Transmission of Context.” American Journal of Sociology 113 (January): 931-69.

Shulman, Robin. 2009. http://www.washingtonpost.com/wpdyn/content/article/2009/08/01/AR2009080102297_pf.html

Tough, Paul. 2008. Whatever it Takes: Geoffrey Canada's Quest to Change Harlem and America. New York: Houghton Mifflin Harcourt.

Wallin, Bruce A. 2005. "Budgeting for Basics: The Changing Landscape of City Finances," discussion paper prepared for the Brookings Institution Metropolitan Policy Program. Washington, D.C.: Brookings Institution.

Wilson, William Julius. 1987. The Truly Disadvantaged: The Inner City, the Underclass and Public Policy. Chicago: University of Chicago Press.

Wilson, William Julius. 1996. When Work Disappears: The World of the New Urban Poor. New York: Alfred A. Knopf.

Wilson, William Julius. 2009. More than Just Race: Being Black and Poor in the Inner City. New York: W.W. Norton. 